\title{
Future Primary Teacher's Model Preparation for Collaboration with Heterogeneous Groups of Students
}

\author{
Tetiana Tutova \\ Postgraduate student \\ Dragomanov National Pedagogical University (Ukraine, Kyiv)
}

\begin{abstract}
The article discloses the preparation of future modeling of primary school teachers to collaboration with heterogeneous groups of students. Different opinions on the peculiarities of the models of future teachers' professional training have been investigated. The model is viewed as an attempt to improve of preparation of future primary school teachers. Improving the content, forms and methods of professional training of primary school teachers becomes relevant in the context of implementation of inclusive education in the New Ukrainian school.

In the article it is presented the structural-functional future primary school teachers model training which includes: goals, objectives, methodological approaches and principles, structural and functional components, content, forms, methods, pedagogical conditions, results, criteria, indicators and levels of readiness to collaboration with heterogeneous groups of students.
\end{abstract}

Key words: model of training primary future teachers, professional preparation future primary school teachers, designing, heterogeneous groups, inclusive education, primary school teacher's readiness to collaboration with heterogeneous groups of students.

Introduction New Ukrainian School focuses on a personality of a teacher who at every point, in each class has a number of options available to interact with students being tolerant to them, understanding their needs, inspiring them, being ready to generate teacher own rules and guidelines to influence their harmonious development.

Thus, one of the future teacher primary school preparation objectives at the university level is to prepare students to a pedagogical interaction with different school students in the context of NUS reform [7]. Teacher - student interaction is especially important in the era of digital generation, including students with special educational needs . They compose heterogeneous groups a teacher has to be ready to collaborate with. The key objective of teaching students to teach is developing a model "How to work" with heterogeneous groups.

The educational objective of changeable $21^{\text {st }}$ century society is shaping conditions for every person's self - realization taking into consideration his belonging to one or another heterogeneous group because every person is different for his heterogeneity. A successful realization of the objective deals with: 
- Firstly, diagnosis and stocking of individual peculiarities of students ;

- Secondly, organizing conditions for development of those peculiarities ;

- Thirdly, adaptation of all the students despite their different possibilities for social interaction at equal conditions. That is realized according active introduction of inclusive education.

Among the up to date programs the European International Program "Tempus IV"[4] is considered to be a contemporary teacher preparation program that prepares to work with heterogeneous groups. This project stresses a democratic equality of all people. As a result of the program a new branch of pedagogy "Pedagogy of Diversity" is initiated. The problem of heterogeneity has been one of the most complicated in social policy during a few decades. World UNESCO conference 1994, United Nations Congress 2006, All - German UNESCO Commission 2010, United Nations Convention was adopted by European Councils in 2010 prove the actuality of the problem.

The problem of future teachers preparation to pedagogical interaction with heterogeneous groups of school students raises a particular actuality in modern education and needs the following:

- General scientific analysis of the professional preparation of a future teacher;

- Analysis of future primary school teacher readiness to work in the context of our research.

New Ukrainian School Concept is characterized with changes in the structure and the content of education, that causes the necessity to prepare a primary school teacher as a professional and innovator, who is able to spread and enrich an experience of every student, developing his potential, no matter which heterogeneous group he belongs. The reform helps a personality to socialize in contemporary educational conditions.

Having analyzed the issue of heterogeneity according psychological, pedagogical and social aspects as well as documents concerning the inclusion, we came to the conclusion that, a heterogeneous group - is a group of students with special educational needs, that have visible characteristics (age, sex, race) and invisible ones (education, intellectual capability, life experience, well brought up, nationality, beliefs, life and moral principles, sexual orientation, etc.), united by mutual criteria (ethnical and religion belonging, health conditions, psychological and physical peculiarities, social status, intellectual potential, creativity, social 
and emotional characteristics, subculture), are interdependent and need additional support in educational process[11].

The primary school teachers preparation is reflected in a number of official documents at a state level. They regulate the activity of educational establishments and prove that education is a foundation of development of a personality, society, nation and the country that help the development of the future of Ukraine.

The challenge of educational refreshment needs is reflected in works of a number of scholars of Ukraine but their investigations don't reflect the fundamental research of the state of primary school teachers preparation for a pedagogical interaction with heterogeneous groups.

The objective of the article is to analyze contemporary models of future teachers preparation for pedagogical activity and presentation of a structural- component model of future primary school teacher preparation for a pedagogical interaction with heterogeneous groups of students.

Before we analyze models of the future primary school teachers preparation it is important consider the meaning of the notion "a model". In science, a model is a representation of an idea, an object or even a process or a system that is used to describe and explain phenomena that cannot be experienced directly. Models are central to what scientists do, both in their research as well as when communicating their explanations. In time the word developed into the meaning as a theory, a hypothetical description of a complex entity or process.

We consider the object of modeling as a part of the process of primary school teachers preparation when the students are taught to get ready for a pedagogical interaction with heterogeneous groups of students. University students get their readiness for a certain activities they will be able to complete.

Modeling in pedagogics is used to realize such tasks as educational planning improvement, learning material structure development, learning and educational activity guidance. Those components improve the quality of education.

Introducing the conception of a model of future primary school teachers preparation for pedagogical interaction with heterogeneous groups of students we take into consideration the main issue of humanistic (the third force) and humanitarian paradigm of education, professionalism of primary school teachers that meet the social demands, standards of higher education and syllabus of professional preparation of future primary school teachers. All those 
meets the national program "XXI Century Education in Ukraine that considers a human as the greatest social value and the task is to discover his abilities, his educational needs realization, importance of harmonious relationships between people in a society[2;5;8;9;10].

A number of educators have developed different models of professional development of future primary school teachers (O.Matviienko and etc) [6]. They have various components, qualities, characteristics, learning process description of teacher preparation, outline steps and structure of professional development, define tasks, principles and technologies of learning and teaching.

When designing the model, we have set the task to improve primary school teacher preparation for pedagogical interaction with heterogeneous groups. One important issue in this design is introduction to university students the pedagogics of variety, methodology, heterogeneity in education that help them to develop professional qualities, skills and multi dimensional pedagogical thinking to interact with heterogeneous groups.

The structure of the model reflects main elements of the process of primary school teacher preparation for pedagogical interaction with heterogeneous groups of school students. They are:

- Objective module (objective, task, result);

- Methodological module (attitude, principles);

- Organizational and technological module (components of readiness, content, forms and methods);

- Activities and results module (criteria, indicators, levels and pedagogical conditions).

Future primary school teacher preparation for interaction with heterogeneous groups of school students model is a description and theoretical background of modules of this process.

Objective module of the model has to form the readiness of future primary school teacher for pedagogical interaction with heterogeneous groups of students that is based on formation of the fundamental knowledge of heterogeneity, shaping a contemporary type of thinking, developing professional and personal qualities of a future professional under the condition of inclusion. New Ukrainian School reform highlights the importance of the teacher - student collaboration with students with special educational needs and thus heterogeneous groups.

Theoretical and methodological module includes a number of general scientific attitudes (valuable, axiological, systemic humanistic, special- organizational). 
Organizational and technological module realizes the function of the model taking into consideration the steps in future teachers professional formation with the following components content: motivational and valuable, informational and cognitive, communicative and reflective - dynamic.

Activities and results module includes the model of future primary school teachers preparation for pedagogical interaction with heterogeneous groups of students taking into account the levels (high, average and beginners). The effectiveness of the preparation is evaluated with the help of criteria: motivational, informational and cognitive communicative, reflective and methodology of pedagogical appreciation readiness of young teachers to interaction with heterogeneous groups.

There are several levels of pedagogical conditions that form the foundation of primary teacher preparation to interact with heterogeneous groups. The first level is personality characteristics of university students that cause the productivity of educational process. The second level includes the pedagogical conditions in its general meaning: teaching content of students, interpersonal group interaction skills development, teacher - students relationship, adaptation of students to the environment and interaction of the educational establishment with the community. The pedagogical conditions of the second level reflect the system of primary school teacher preparation for pedagogical interaction with heterogeneous groups. The personality characteristics of students have to be taken into consideration when forming pedagogical conditions and developing a strategy of model realization in educational process at higher educational establishment. In conclusion we have to stress that primary school teacher preparation for interaction with heterogeneous groups is effective only under some pedagogical conditions:

- formation of positive motivation for pedagogical activity of students taking into consideration heterogeneous and inclusive educational environment;

- professional development of primary school teachers via subject - subject interaction with improvement of their preparation at the university level;

- activation of student personal and professional qualities for professional activities that meets New Ukrainian School Concept;

- future primary school teachers preparation for practical activity under conditions of heterogeneity of primary school students. 
Our investigations allow us to come to conclusion that the successful function of the model of primary school teachers preparation for interaction with heterogeneous groups is possible under a condition of important criteria mentioned in the article.

Conclusion. The result of the preparation is formation of readiness of future primary school teachers for pedagogical interaction with heterogeneous groups is personality development that promotes high results of teacher collaboration with heterogeneous groups. The development includes professional and moral qualities of a teacher, his values and beliefs, readiness to collaborate with students, professional competency, tolerance, knowledge, skills and habits, experience in organizing of a pedagogical interaction with heterogeneous groups, acceptance of heterogeneity in education, ability to face and overcome difficulties in collaboration with heterogeneous groups of primary school students, predicting and warning them, ability for self - improvement.

The realization of the model opens perspectives of a teacher professional development and readiness to face the educational challenge to collaborate with heterogeneous groups at primary school.

\section{References}

1. N. V. Sankova, A. A. Trejtjak (2016). "Inclusive education from A to Z: a guide for teachers and parents"/- K.,- P. 68.[ in Ukrainian]

2. Decree of the President of Ukraine (2002) № 347. "National doctrine of the development of education in Ukraine in the XXI century". Retrieved from http://zakon5. rada. gov.ua/laws/show/347/2002 [ in Ukrainian]

3. Dubasenyuk O.(2008)."Conceptual models of pedagogical education: scientific research and achievements". Zhytomyr: ZhSU Publishing House. I. Franko.p.8-29[in Ukrainian]

4. Joint European project TEMPUS IV/VI (2013)"Training of teachers and educational managers to work with heterogeneous groups and organizations" 543873-TEMPUS-1-2013-1DE-TEMPUS-JPCR. Retrieved from http://tempus 2013-16.novsu. ru/mod/page. [in Ukrainian]

5. Law on Education in Ukraine (2017). Retrieved from http://zakon.rada. gov.ua/laws/show/2145-19 [in Ukrainian]

6. Matvienko O.(2009) "Training of future teachers for pedagogical coloboration": monograph. NPU named after M. Drahomanov,384 p. [in Ukrainian]

7. Ministry of Education and Science. (2017)"New Ukrainian School". Retrieved from http:// https://mon.gov.ua/ua/tag/nova-ukrainska-shkola [ in Ukrainian] 
8. State National Program "Education". "Ukraine of the XXI century'. (1994). Kyiv, 61 p.[in Ukrainian]

9. The Cabinet of Ministers of Ukraine. (2002). State program "Teacher". № 379. Retrieved from http://zakon4.rada.gov.ua/laws/show/379-2002-\%D0\%BF [in Ukrainian]

10. The Law on «Higher Education» in Ukraine (2014). Retrieved from http://osvita. ua/legislation/law/2235/list/1/[in Ukrainian]

11. Tutova T. (2019) “Future primary school teacher's readiness to collaboration with heterogeneous groups of students as a component of professional preparation". Scientific journal. Issue 10.T.3 Odessa, p.103-107.[in Ukrainian] 